\title{
PROTECTION OF ATHYMIC (NU/NU) BALB/C MICE AGAINST PLASMODIUM BERGHEI BY SPLENOCYTES FROM NORMAL (NU/+) BALB/c MICE (")
}

José J. FERRARoni (1,2), Thomas G. DOUGLASS (2) and Clarence A. SPEER (2)

S U M M A R Y

Athymic $\mathrm{BALB} / \mathrm{c}(\mathrm{Nu} / \mathrm{Nu})$ mice died at $7-13$ days after inoculation (DAI) of Plasmodium berghei NK65, whereas their heterozygous $(\mathrm{Nu} /+)$ littermates died at 7-8 DAI. Nude $(\mathrm{Nu} / \mathrm{Nu})$ mice, reconstituted with $2 \times 10^{7}$ splenocytes from uninfected heterozygous $(\mathrm{Nu} /+)$ littermates at 20 days before parasite inoculation (DBI), died about 2 days earlier than control nude mice; nude mice reconstituted at 10 or 2 DBI lived 2 to 4 days longer than control nudes; and nude mice reconstituted 2 DAI lived even longer and some survived. These findings indicate that P. berghei NK65 induces at least two T-cell dependent immune phenomena, one suppressive and the other stimulatory. Reconstitution of nude mice with T-cells from BALB/c (Nu/+) mice appeared to reduce or bypass suppressive T-cell activities which allowed the formation of a protective immune response by some of the nude mice.

\section{NTRODUCTION}

Several species of rats and voles serve as hosts for the NK65 strain of Plasmodium ber. ghei in which the infection is rarely fatal 2,18. However, the NK65 strain of P. berghei has been found to be $100 \%$ lethal for all strains of laboratory mice tested to date $13,25,26,27,33,37$. Long lasting immunity to P. berghei NK65 has been achieved only by using parasite inoculation and drug cure (ELING; FERRARONI \& SPEER) 8,11 . Lymphocytes from such solidly immune animals are capable only of transferring some degree of resistance to $P$. berghei (FERRARONI \& SPEER) ${ }^{12}$. Acquired resistance to plasmodia has been shown to depend upon both bone marrow and thymus-derived lymphocytes ${ }^{3}$. However, in a preliminary study we found that naive athymic nude mice inoculated with $P$. berghei NK65 survived significantly ionger than their hirsute $(\mathrm{Nu} / \mathrm{+})$ littermates. Recently, WAKI \& SUZUKI 38 were able to abrogate resistance to $P$. berghei NK65 by reconsti. tuting athymic nude mice with thymocytes at three weeks before parasite inoculation.

It is still not known how soon after reconstitution by thymocytes that athymic mice become immunologically competent. The effects of reconstitution on both humoral ${ }^{14}$ and cell. mediated 19,32 immunity have been determined only for three or more weeks after thymic implantation or injection of thymocytes.

In order to determine the efficacy of ma ture lymphocytes upon $\mathbf{P}$. berghei infections in athymic nude mice, splenic lymphocytes and culture-derived spleen cell supernatants from

(*) This study is based on a dissertation submitted by J. J. Ferraroni to the Graduate School of the University of Montana in partial fulfiliment to the requirements for the Doctor of Philosophy degree

(1) Universidade do Amazonas/CNPq, Campus Universitário, Departamento do Patologia - ICB - 69.000, Manaus, Amazonas, Brasil

(2) Department of Microbiology, University of Montana, Missoula, Montana, 59812 - USA 
FERRaroni, J. J.; DOUGLass, T. G. \& SPEER, C. A. - Protection of athymic (Nu/Nu) BaLB/c mice against Plasmodium berghei by splenocytes from normal $(\mathrm{Nu} /+)$ ) BALB/c mice. Rev. Inst. Med. trop. São Paulo 27:303-311, 1985.

naive heterozygous $(\mathrm{Nu} /+)$ mice were adoptively transferred to nude mice at various intervals before or after parasite inoculation. The results obtained from these studies are reported herein.

\section{MATERIALS AND METHODS}

Animals - Congenic atnymic nude ( $\mathrm{Nu}$ / $\mathrm{Nu}) \mathrm{BALB} / \mathrm{c}$ mice and their hirsute $(\mathrm{Nu} / \mathrm{+})$ littermates were raised in the Microbiology Department animal facility at the University of Montana. All mice were 8-weeks-old at the beginning of each experiment, except for experiment No. 3 in which the athymic mice were 5weeks-old. Mice 'were kept in covered cages with sterile sawdust and fed sterile mouse lab chow ad libitum. Tetracycline $(5 \mathrm{mg} / 1)$ in sterile water was given ad libitum to the mice until 10 days before parasite inoculation. SwissWebster outbred mice served as hosts for parasite maintenance. The University of Montana GALB/c athymic mouse colony and Swiss-Web. sier mice were originally obtained from the National Institute of Allergy and Infectious Diseases, Rocky Mountain Laboratory, Hamilton, MT.

Parasite, Plasmodium berghei NK65 was originally obtained from the University of New Mexico, Albuquerque, NM, and had been maintained by weekly blood passages in Swiss-Webster mice for $5 \mathrm{yr}$ before being used in this study. Parasitized blood was obtained from Swiss-Webster or BALB/c mice and washed 3 times in phosphate buffered saline (PBS) at $4^{\circ} \mathrm{C}$ 'without anticoagulant. All mice were injectec. intraperitoneally (IP) with $10^{7} \mathbf{P}$. bergheiinfected erythrocytes. The interval between bleeding donor mice and inoculating the infecteci blood into recipient mice was less than 40 min. The parasitemia was determined for each animal by microscopic examination (oil immersion lens) of cells in peripheral blood smears stained with Giemsa.

Splenocytes - Spleens were removed aseptically from 8 to 10 week-old donor $B A L B / c$ $(\mathrm{Nu} /+)$ mice and forced through a 60-mesh stainless steel screen into Minimal Essential Medium (MEM, Gibco, Santa Clara, CA), pH 7.4, containing $100 \mu \mathrm{g} / \mathrm{mI}(\mathrm{W} / \mathrm{v})$ streptomycin sul. fate and $100 \mathrm{U} / \mathrm{ml}(\mathrm{w} / \mathrm{v})$ potassium penicillin
G. After allowing the tissue debris to settle for $10 \mathrm{~min}$, the cell supernatant was removed and washed three times with MEM. Erythrocytes were lysed with $0.15 \mathrm{M}$ ammonium chloride, after which the remaining nucleated cells were washed three times in PBS. Nucleated cells less than $10 \mu \mathrm{m}$ in diameter were found to be $96 \%$ viable as determined by trypan blue exclusion. Each recipient animal was injected IP with 0.2 m1 MEM containing $2 \times 10^{7}$ viable splenocytes.

In order to compensate for two major variables (i.e., splenocytes and parasite inocula), two cell transfer experiments were performed. In the first experiment, all animals received splenocytes from the same preparation, whereas fresh inocula of $\mathbf{P}$. berghei were obtained from mice at the time of each parasite inoculation. Nine groups of 6 mice each ( 3 males and 3 females) were used. Groups 1-6 and 7-9 were BALB/c athymic ( $\mathrm{Nu} / \mathrm{Nu}$ ) and BALB/c $(\mathrm{Nu} /+)$, respectively. Groups 1-5 received splenocytes at 20,10 or 2 days before parasite inoculation (DBI), at the time of parasite inoculation (DOI), or 2 days after parasite inoculation (DAI), respectively. Splenocytes were given to group 7 two DAI and to group 8 at DOI. Groups 6 and 9 received no splenocytes and served as controls.

In the second experiment, all animals were inoculated with the same parasite preparation, whereas splenocytes were obtained from mice at the time of each cell transfer. Four groups of $7 \mathrm{BALB} / \mathrm{c}(\mathrm{Nu} / \mathrm{Nu})$ mice $(4$ males and $3 \mathrm{fe}$ males) were used. Groups 1-3 received splenocytes at two DAI, one DAI or at DOI, respectively. Group 4 received no splenocytes and served as a control.

Splenocyte supernatants - Three types of splenocyte supernatants (SCS 1, 2 and 3) were obtained as follows. Eight hundred million splenocytes suspended in $50 \mathrm{ml}$ MEM contain. ing $5 \%$ fetal calf serum (FCS) were inoculated into each of three $32 \mathrm{oz}$ Brockway culture flasks and then incubated at $37^{\circ} \mathrm{C}, 5 \% \mathrm{CO}_{2}, 95 \%$ air. Spleen cell culture No. 1 was cultured $24 \mathrm{~h}$ in the presence of $5 \mu \mathrm{g} / \mathrm{ml}$ Concanavalin A (Con A, Sigma Chemical Co., St. Louis, Mo.); after $24 \mathrm{~h}$ incubation, $5 \mu \mathrm{g} / \mathrm{ml}$ Con A were added to culture No. 2; culture No. 3 was incubated 24 h without Con A. After incubation, the superna. tant was removed from each culture flask, cen- 
FERRARONI, J. J.; DOUGLASS, T. G. \& SPEER, C. A. - Protection of athymic (Nu/Nu) BALB/c mice against Plas. modium berghei by splenocytes from normal $(\mathrm{Nu} /+)$ BAT.B/C mice. Rev. Inst. Med. trop. São Paulo 27:303-311, 1985.

trifuged at $450 \mathrm{~g}$ for $5 \mathrm{~min}$, dialized $16 \mathrm{~h}$ at $4^{\circ} \mathrm{C}$ in 751 distilled water and then concentrated $\sim$ 20 times by $6 h$ of evaporation dialysis.

Each mouse in three groups of $5 \mathrm{BALB} / \mathrm{c}$ $(\mathrm{Nu} / \mathrm{Nu})$ mice 'was injected IP with $0.5 \mathrm{ml}$ SCS 1, 2 or 3 (approximately the amount derived from $2 \times 10^{7}$ splenocytes) at two DAI of P. berghei. One group of $5 \mathrm{BALB} / \mathrm{C}(\mathrm{Nu} / \mathrm{Nu})$ mice served as an untreated control.

In order to determine the efficacy of nude and heterozygous mice to clear parasites from their peripheral circulation, $0.5 \mathrm{ml}$ of blood containing $2.5 \times 10^{7} \mathrm{P}$. berghei-infected red blood cells was injected intravenously into each of two nude mice and two heterozygous mice. The parasitemia of each animal was determined by microscopic examination of blood smears stained "with Giemsa at varying intervals, starting at $2 \mathrm{~min}$ and ending after $18 \mathrm{hs}$. Significant differences among various experimental groups were determined by the Stu. dent's t-test at $\mathbf{P}$ values of -0.05 .

\section{RESULTS}

Course of $P$. berghei infection - Figure 1 shows the mean daily parasitemia (MDP) up until the time of death of $\mathrm{BALB} / \mathrm{C}$ athymic mice inoculation with $P$. berghei at various times relative to their receiving $2 \times 10^{7}$ splenocytes from the same splenocyte preparation. Table I gives the mean day of death (MDD) and the mean parasitemia the day prior to death. Because two of the athymic mice in the group which received splenocytes 2 DAI survived and their parasitemia never exceeded $1 \%$ (Table III), they were not included in Fig. 1. The MDP and the MDD of the athymic mice which received splenocytes $20 \mathrm{DBI}$ did not differ significantly from those of control nude mice. In the other groups, there was a direct correlation between the beneficial effects of splenocytes and the time of splenocyte transfer relative to time of parasite inoculation (Fig. 1). The MDP rose slower and the mice survived longer in nude mice which received splenocytes at $10 \mathrm{DBI}, 2 \mathrm{DBI}, \mathrm{DOI}$ and $2 \mathrm{DAI}$ than in control mice. Splenocytes given $2 \mathrm{DAI}$ caused more delay in rise of parasitemia as well as in day of death. It was in this group only that animals survived.

$$
\text { T A B L E I }
$$

Plasmodium berghei infection in athymic BALB/c (Nu/Nu) mice with or without reconstitution with splenocytes from $\mathrm{BALB} / \mathrm{c}(\mathrm{Nu} / \mathrm{H})$ mice, from the same splenocyte preparation

\begin{tabular}{ccccc}
\hline & $\begin{array}{l}\text { Number of } \\
\text { Group of splenocyte }\end{array}$ & $\begin{array}{l}\text { Mean } \\
\text { surving } \\
\text { animals } \\
\text { day of } \\
\text { death }\end{array}$ & $\begin{array}{l}\text { Mean \% par. } \\
\text { asitemia } \\
\text { day prior } \\
\text { to death }\end{array}$ \\
\hline 1 & 20 DBI & 0 & 11 & 77.2 \\
2 & 10 DBI & 0 & 13 & $83.5^{2}$ \\
3 & 2 DBI & 0 & 15 & 73.5 \\
4 & DOI & 0 & 19 & 80.5 \\
5 & 2 DAI & 2 & 21 & $79.3^{2}$ \\
6 & $*$ & 0 & 11 & 76.0 \\
\hline
\end{tabular}

$1=6$ mice per group

$2=1$ death not due to the malarial infection

* $=$ Controls received no splenocytes

DAI = Days after parasite inoculation

DBI = Days before parasite inoculation

$D O T=$ Day of parasite inoculation

Figure 2 shows the MDP until the time of death of nude and heterozygous $(\mathrm{Nu} /+)$ mice which were infected with the same inoculum of $P$. berghei but which received splenocytes from different preparations at the same time of one or 2 DAI. Table II gives the MDD and the mean parasitemia the day prior to death for the sa. me mice. No significant differences were observed between control heterozygous $(\mathrm{Nu} /+)$ mice and heterozygous mice that received splenocytes (Table I). Heterozygous mice always succumbed earlier with a lower parasitemia than nude mice. Because four of the nude mice which received spleen cells 2 DAI survived and their parasitemia never exceeded 1\% (Table III), their MOP was not included in Fig. 2. As noted in the previous experiment, a direct correlation existed between the benificial effect of the time of splenocyte transfer and the time of parasite inoculation. The greatest beneficial effect was observed in those mice that receiv. ed splenocytes at $2 \mathrm{DAI}$; their parasitemia remained relatively low $(<5 \%)$ for $17 \mathrm{DAI}$ and then increased to $>85 \%$ by 27 DAI, which was also the MDD.

Table III gives the individual daily parasitemia of mice which received splenocytes 2 DAI in experiments 1 and 2 . In experiment 1 , parasites were present in the peripheral blood of all mice (except mouse No. 2) from day six until death or resolution of the infection. In experiment No. 2 parasites were usually not observed at 9 to 17 DAI after which parasites 


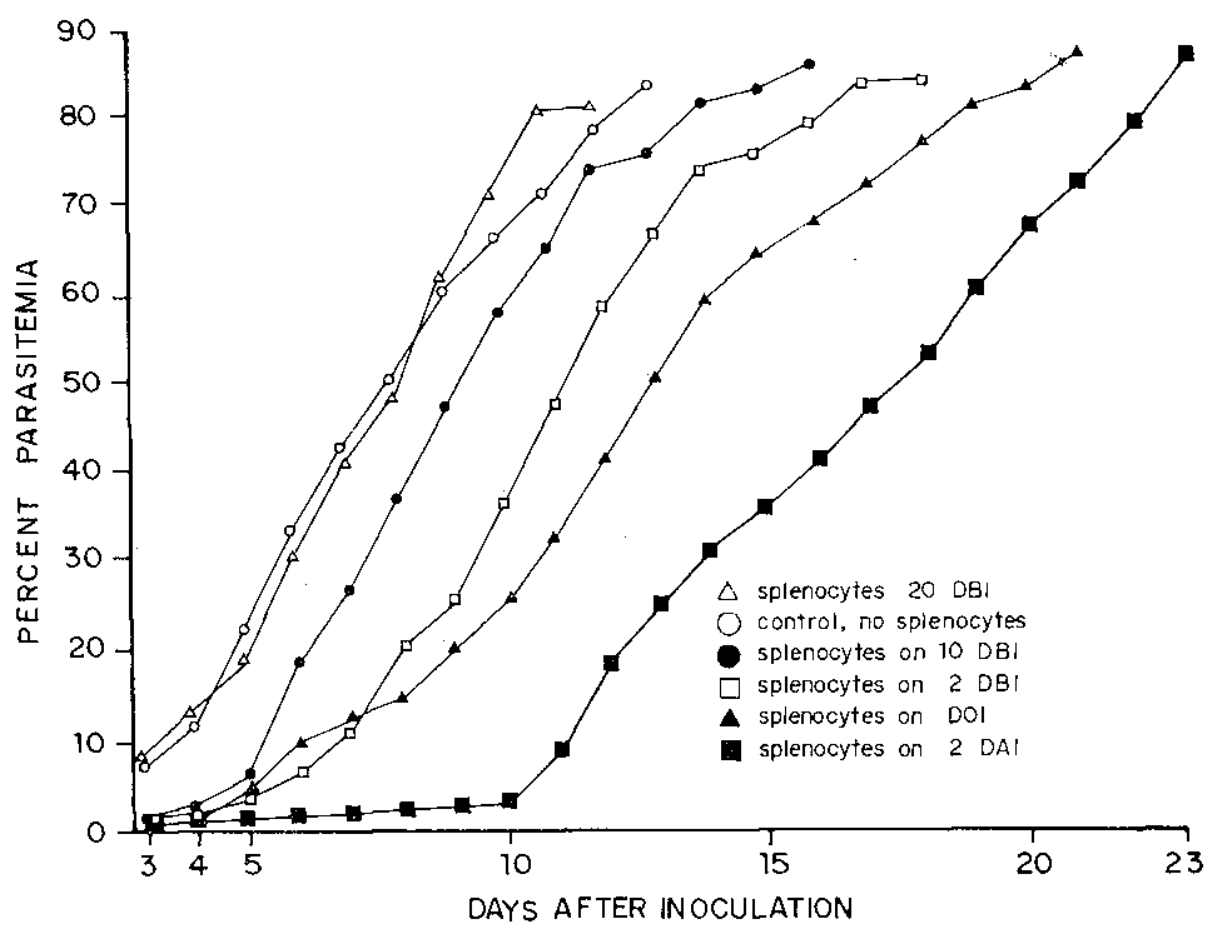

Fig. 1 - Mean daily parasitemia of $\mathrm{BALB} / \mathrm{c}(\mathrm{Nu} / \mathrm{Nu})$ and phenotypically normal $(\mathrm{Nu} / \mathrm{H})$ mice inoculated with $10^{7} \mathbf{P}$. berghei-parasitized erythrocytes from different sources and splenocytes from the same preparation from $B A L B / c(N u /+)$ mice; $\Delta$, received spienocytes $20 \mathrm{DBI} ; O$, control, received no splenocytes; - , received splenocytes $10 \mathrm{DBI} ; \square$, received splenocytes $2 \mathrm{DBI} ; \mathbf{A}$, received splenocytes DOI; $\boldsymbol{m}$, received splenocytes 2 DAI.

\section{T A B I E II}

Plasmodium berghei infection in $\mathrm{BALB} / \mathrm{C}(\mathrm{Nu} / \mathrm{Nu})$ and $(\mathrm{Nu} /+)$ mice given splenocytes from $(\mathrm{Nu} /+)$ mice at the time of or at 1 or 2 days after parasite inoculation. All animals were inoculated with the same parasite preparation

\begin{tabular}{|c|c|c|c|c|c|}
\hline Group1 & $\begin{array}{l}\text { Mouse } \\
\text { Genotype }\end{array}$ & $\begin{array}{l}\text { Day of } \\
\text { spleen cell } \\
\text { inoculation }\end{array}$ & $\begin{array}{l}\text { Animal } \\
\text { survival }\end{array}$ & $\begin{array}{l}\text { Mean } \\
\text { day of } \\
\text { death }\end{array}$ & $\begin{array}{l}\text { Mean \% par- } \\
\text { asitemia } \\
\text { day prior } \\
\text { to death }\end{array}$ \\
\hline 1 & $(\mathrm{Nu} / \mathrm{Nu})$ & $2 \mathrm{DAI}$ & 4 & 27 & 85.0 \\
\hline 2 & $"$ & 1. DAI & 0 & 17 & 85.0 \\
\hline 3 & $"$ & DOI & 0 & 15 & 84.5 \\
\hline 4 & $"$ & * & 0 & 11 & 85.7 \\
\hline 5 & $(\mathrm{Nu} /+)$ & * & 0 & 8 & 56.0 \\
\hline 6 & $"$ & $2 \mathrm{DAI}$ & 0 & 8 & 62.0 \\
\hline
\end{tabular}

$1=7$ mice per group

* = Controls received no splenocytes

DAI = Days after parasite inoculation

DOI $=$ Day of parasite inoculation

reappeared in the peripheral blood. After the parasites reappeared in the blood, the infection proceeded until the mice died or the infection was resolved.
Figure 3 shows the MDP of nude mice that received SCS 2 DAI of $10^{7} \mathbf{P}$. berghei-parasitized erythrocytes. No significantly differences occurred between the groups of nude mice which received SCS 1, 2, or 3 and the control group.

The heterozygous mice were more effica. cious in removing infected red cells from their peripheral circulation than nude mice (Table IV).

\section{DISCUSSION}

WAKI \& SUZUKI ${ }^{38}$ found that athymic nu. de $(\mathrm{Nu} / \mathrm{Nu})$ mice infected with $P$. berghei NK65 survived significantly longer than their hirsute $(\mathrm{Nu} /+)$ littermates. They also found that the survival time of nude mice that had been reconstituted with neonatal thymocytes from hirsute mice three weeks before parasite inocula. tion was not significantly different than that of their thymic competent littermates. Based upon these observations, these authors suggest. ed that nude mice lived longer during a $\mathbf{P}$. 
FERRARONI, J. J.; DOUGLASS, T. G. \& SPEER, C. A. - Protection of athymic (Nu/Nu) BALB/c mice against Plasinodium berghei by splenocytes from normal (Nu/+) BALB/c mice. Rev. Inst. Med. trop. São Paulo 27:303-31l, 1985.

T A B L E III

Individual daily Parasitemia of athymic (Nu/Nu) BALB/c mice which received $2 \times 10^{\circ}$ splenocytes from normal heterozygous ( $\mathrm{Nu} / \mathrm{+}$ ) BALB/c mice two days after inoculation with Plasmodium berghei

\begin{tabular}{|c|c|c|c|c|c|c|c|c|c|c|c|c|c|c|c|c|c|c|c|c|c|c|c|c|}
\hline \multirow{2}{*}{$\dot{z}$} & \multirow{3}{*}{$\begin{array}{l}\dot{0} \\
8 \\
\stackrel{8}{8} \\
1\end{array}$} & \multicolumn{23}{|c|}{ Days after parasite inoculation } \\
\hline & & 6 & 7 & 8 & 9 & 10 & 11 & 12 & 13 & 14 & 15 & 16 & 17 & 18 & 19 & 20 & 21 & 22 & 23 & 24 & 25 & 26 & 27 & 28 \\
\hline \multirow{6}{*}{ 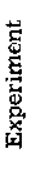 } & & $1(*)$ & 2 & 5 & 11 & 14 & 17 & 21 & 27 & 33 & 36 & 40 & 49 & 58 & 69 & 75 & $-(+\infty)$ & - & $\cdots$ & - & - & - & - & - \\
\hline & 2 & 0 & .1 & .1 & .1 & .1 & .1 & .1 &.$I$ & .1 & & & & & & .1 & .1 & .1 & .1 & .1 & .1 & .1 & & \\
\hline & 3 & .1 & .1 & .1 & 2 & 3 & 5 & 8 & $-(* *)$ & - & $\longrightarrow$ & 一 & - & 一 & - & $\leftarrow$ & 一 & - & - & - & - & - & - & - \\
\hline & 4 & .1 & .1 & .1 & .1 & .1 & & & & & & & & & & & & & & & & & & \\
\hline & 5 & .1 & .1 & 1 & 2 & 5 & 7 & 11 & 14 & 20 & 27 & 34 & 29 & 46 & 52 & 63 & 68 & 75 & 78 & $-(* *)$ & - & - & - & - \\
\hline & 6 & 1 & 3 & 5 & 8 & 11 & 13 & 20 & 27 & 31 & 37 & 43 & 39 & 53 & 56 & 70 & 76 & 81 & 85 & $-(*)$ & - & - & - & - \\
\hline ov & 1 & $.1\left(^{*}\right)$ &.$I$ & & & & & & & & & & .1 & .8 & 15 & 27 & 39 & 48 & 60 & $\therefore 9$ & 75 & 80 & 85 & - $(*)$ \\
\hline \multirow{2}{*}{ ¿ } & 2 & & & & & & & & & & & & & .3 & 20 & 31 & 42 & 50 & 59 & 68 & 79 & 84 & $-\left(^{* * *}\right)$ & \\
\hline & 3 & .1 & .2 & .1 & & & & & & & & & & .1 & .8 & .8 & .5 & .3 & .2 & .2 & .1 & .1 & & \\
\hline \multirow{4}{*}{ 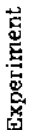 } & 4 & .1 & .1 & .1 & .1 & & & & & & & & .2 & 1 & 17 & 26 & 34 & 45 & 53 & 67 & 73 & 79 & 86 & $-(* x)$ \\
\hline & 5 & & & & & & & & & & & & & .1 & .5 & .7 & .5 & .2 & .1 & & & & & \\
\hline & 6 & .1 & .2 & .1 & .1 & & & & & & & & & & & & .1 & .2 & .1 & .1 & & & & \\
\hline & 7 & .1 & .1 & & & & & & & & & & & & & & & & & & & & & \\
\hline
\end{tabular}

(*) Percent parasitemia

(**) Day of death

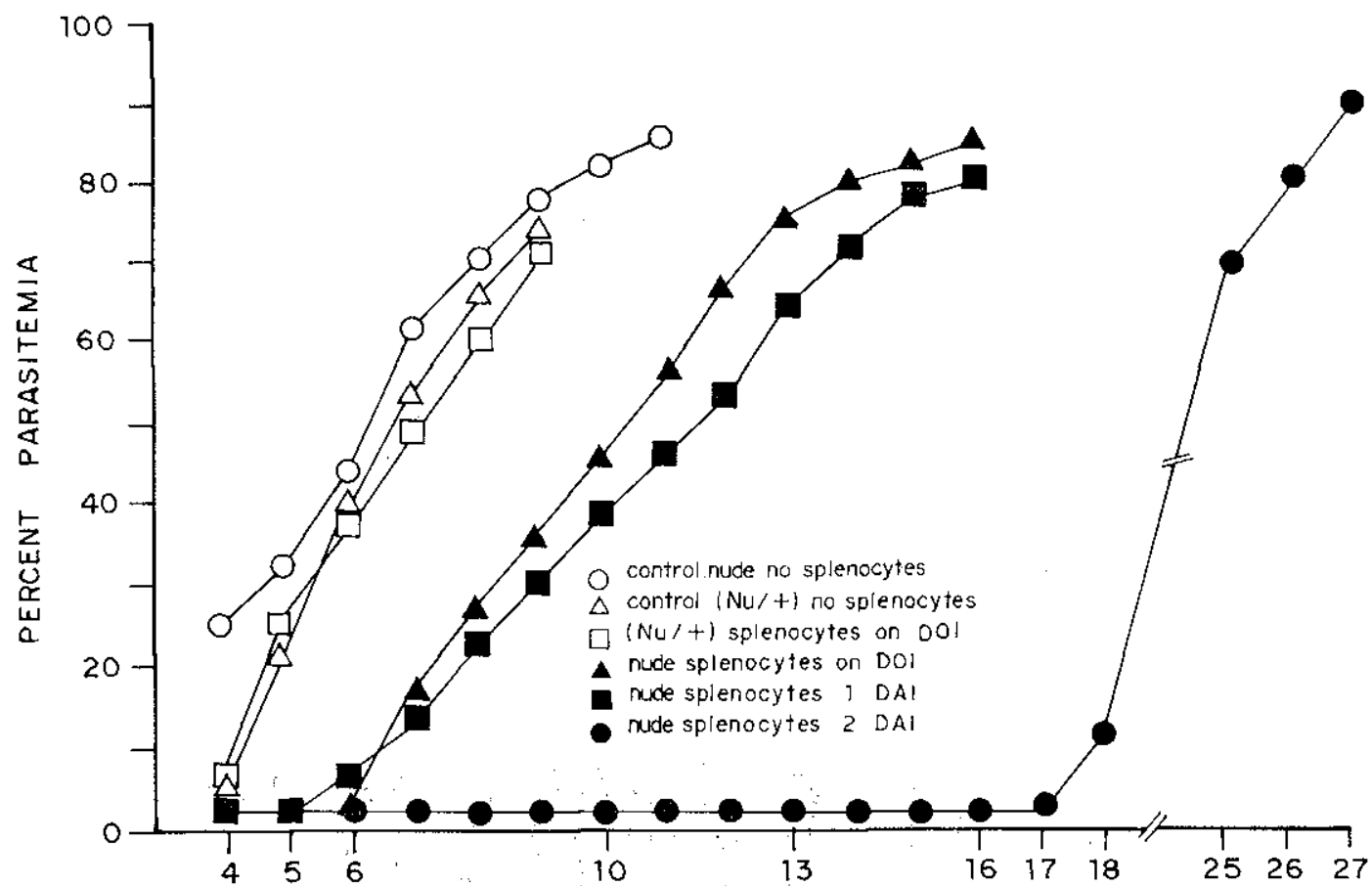

Fig. 2 - Mean daily parasitemia of BALB/c nude mice which received splenocytes from different heterozygous $\mathrm{BALB} / \mathrm{C}(\mathrm{Nu} /+)$ sources after inoculation of $10^{7} \mathbf{P}$. herghei-infected erythrocytes. $O$, control nude mice, received no splenocytes; $\triangle$, control heterozygous (Nu/t) mice, received no splenocytes; $\square, B A L B / c(N u /+)$ mice received splenocytes DOI; $\boldsymbol{A}$, nude mice received splenocytes DOI; , nude mice received splenocytes 1 DAI; nude mice received splenocytes 2 DAI

berghei NK65 infection because they lacked a T-cell-dependent immunopathologic response. The results obtained in the present study indi- cate that there is no immunopathologic response associated with mature splenic derived T-cells in mice infected with $P$. berghei NK65. We 
FERRARONI, J. J.; DOUGLASS, T. G. \& SPEER, C. A. - Protection of athymic (Nu/Nu) BALB/C mice against Plasmodium berghei by splenocytes from normaI (Nu/+) BALB/c mice. Rev. Inst. Med. trop. São Paulo 27:303-311, 1985.

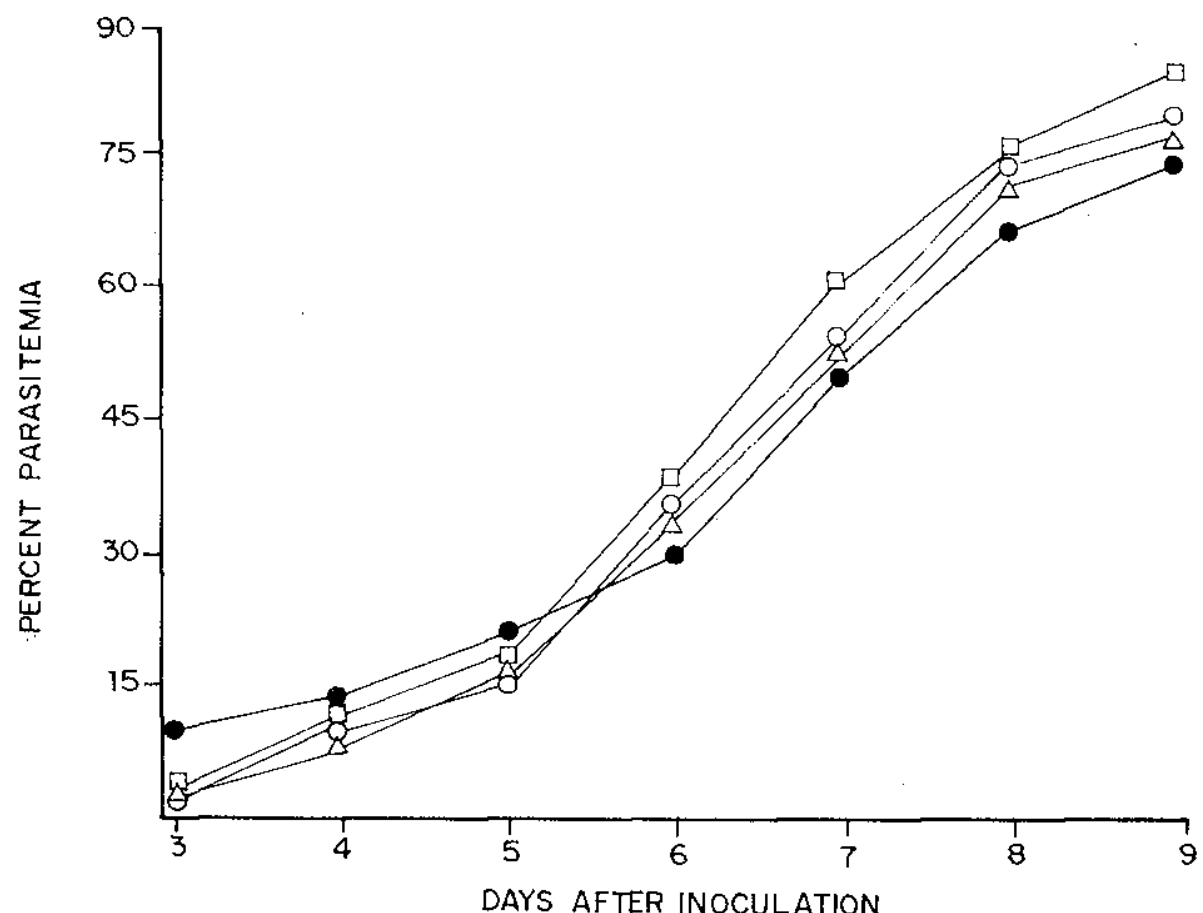

Fig 3 - Mean daily parasitemia of $B A L B / C$ nude mice receiving splen cell supermatant (SCS) from splenocytes of BALB/c $(\mathrm{Nu} /+)$ mice with or without ConA and inoculated with $10^{-} \mathbf{P}$. bergheiparasitized erythrocytes 2 DAI. - control, no SCS; O, SCS; $\triangle$. from splenocytes cultured in presence of ConA for $24 \mathrm{hr}$; $\square$, SCS from splenocytes cultured for $24 \mathrm{hr}$ and then treated with ConA

\section{T A B L E IV}

Clearance of P. berghei - infected erythrocytes from the blood of $(\mathrm{Nu} / \mathrm{Nu})$ and $(\mathrm{Nu} /+) \mathrm{BALB} / \mathrm{C}$ mice at 2 to 1080 min after intravenous inoculation of $2.5 \times 10^{7}$ infected erythrocytes

\begin{tabular}{rcc}
\hline Time in $\min$ & $(\mathrm{Nu} / \mathrm{Nu})$ & $(\mathrm{Nu} / \mathrm{+})$ \\
2 & 0.12 & 0.11 \\
15 & 0.10 & 0.05 \\
45 & 0,12 & 0.05 \\
90 & 0.08 & 0.02 \\
120 & 0.10 & 0.00 \\
240 & 0.11 & 0.005 \\
360 & 0.17 & 0.004 \\
1080 & 0.54 & 0.002 \\
\hline
\end{tabular}

(1) Number represents mean of percent parasitemia

found that nude mice reconstituted with sple. nocytes at $20 \mathrm{DBI}$ showed no benificial or harm. ful effect and that those reconstituted at 10 or fewer DBI or at 2 DAI showed a decrease in onset of parasitemia and an increased survival time, and some mice even survived. Reconstitution with neonatal thymocytes probably provi. des a greater number of T-cell recognition and effector functions than reconstitution with splenocytes. Reconstitution of nude mice with thy: mocytes at three weeks before inoculation may allow sufficient time for the development of suppressor T-cell activity. Splenocytes may lack a full complement of T-cell subsets necessary to generate suppressor T-cell activity of a magnitude similar to that obtained by thymocyte reconstitution as observed by WAKI \& SUZUKI ${ }^{38}$. Thus, $\mathbf{P}$. berghei appears to induce at least two T-cell dependent immune phenomena, one suppressive and the other stimulatory. Reconstitution of nude mice with splenocytes from phenotypically normal heterozygous mice appears to reduce or bypass the suppressive Tcell activities which allows the formation of a protective immune response to $\mathbf{P}$. berghei by some of the nude mice.

Several mechanisms are probably involved in the ability of splenocytes from thymic com. petent mice to protect nude mice against $\mathbf{P}$. berghei NK65. Macrophages of nude mice have a greater capacity to phagocytose and kill certain viruses, bacteria and yeasts than macrophages of thymic competent mice (CAU. LEY \& MURPHY 4 ; CHEERS \& WALLER 5; EMMERLING et al. ${ }^{9}$; FAUVE \& HEVIN 10 ; 
FERRARONI, J. J.; DOUGLASS, T. G. \& SPEER, C. A. - Protection of athymic (Nu/Nu) BALB/c mice against Plasmodium berghei by splenocytes from normal $(\mathrm{Nu} / \mathrm{t})$ BALB/c mice. Rev. Inst. Med. trop. São Paulo 27:303-311, 1985.

MONGENSEN \& ANDERSEN 21; NICKOL \& BONVENTRE ${ }^{23}$; ROGER et al. ${ }^{28}$ ). However, enhanced activity by the reticuloendothelial system (RES) does not appear to be respon. sible for the increased survival time and protection against Plasmodium and Babesia by mice that had received Bacille Calmette-Guérin (BCG) or killed Corynebacterium parvun (BAZARMALIK '; CLARK et al. ${ }^{6}$; CLARK, COX \& ALUISON 7; MURPHY 22; NUSSENZWEIG ${ }^{24}$; SMRKOVSKI \& STRICKLAND ${ }^{31}$ ), In the present study, nude mice did not clear malarial parasites from their peripheral blood as rapidly as thymic competent mice. Thus, the delay in onset of parasitemia in nonre. constituted nude mice does not appear to be due to enhanced activity of the RES.

Recently, WAKI \& SUZUKI ${ }^{39}$ reported that nude mice infected with $\mathbf{P}$. berghei and cured by pyrimethamine primed the animals so that a secondary antibody response was elicited upon parasite challenge. They concluded, therefore, that at least one parasite antigen was thymus independent and that primed B-cells were the dominant cells generated during a primary infection in nude mice. However, B-cells can be primed by thymus dependent antigens in the absence of T-cells ${ }^{29}$. Immune serum from mice driven to immunity by re. peated cycles of $\mathbf{P}$. berghei infection and Fansidar cure (pyrimethamine + sulfadoxine) has been found to suppress parasite development in naive mice, but only if administered on a daily basis (FERRARONI \& SPEER) 12 .

Two lines of evidence indicate that antibody is probably not involved in the antimalarial protection of nude mice reconstituted with normal splenocytes. First, WAKI \& SUZUKI ${ }^{39}$ found that nude mice immunized against $\mathbf{P}$. berghei were not protected against parasite challenge even though they developed significant levels of parasite-specific anti. bodies. Second, we found that the nude mice, which had been reconstituted with splenocytes and survived a primary $\mathbf{P}$. berghei infection, succumbed to a challenge inoculation 40 days later (about 10 days after parasite clearance of the first inoculation). Thus, such reconstituted nude mice evidently have no memory of their earlier infection and the factors involved in the elimination of the parasites in the primary infection are short-lived.
Certain investigators $15,16,17,35,41$ have suggested that interferon or interferon-like substances may be responsible for the enhanced resistance to blood protozoa by animals treated with various nonspecific immunopotentiators such as endotoxin, statolon, polyriboinosinic acid, New Castle Disease virus (NDV) and $B C G 1,6,7,16,17,24,30,31,34,36$. JAHIEL et al. 16 found that interferon inducers provided mice with some degree of protection against $\mathbf{P}$. berghei and were able to detect interferon in the serum of mice infected with NDV or treated with statolon. Nude mice are usually infected with mouse hepatitis virus ${ }^{40}$ and presumably support low grade chronic infections with other viruses as well as bacteria. Mature T-cells primed by interaction with various infectious agents already in the nude mice may result in the production of substances which would nonspecifically protect the host against P. berghei. Because we found that the protec. tion afforded by splenocytes was short-lived, interferon does not appear to be the substance responsible for protecting nude mice against P. berghei. However, a short-lived substance prossessing activities similar to those of interferon might have been provided to the nude mice by splenocytes from thymic competent mice. The lability of such an interferon-like substance may account for the fact that the greatest degree of protection of nude mice against $\mathbf{P}$. berghei was obtained when splenocytes were transferred 2 DAI of P. berghei.

During the ontogeny of the immune system the ability to suppress a specific immune response usually develops after the ability to respond to specific antigen ${ }^{20}$. In addition, soluble T-cell suppressor substances are usually not produced for about $48 \mathrm{~h}$ following the interaction of $\mathrm{T}$-cells with specific antigen, whereas T-cell helper substances are known to be produced as early as 12 h 19,32. A greater de. gree of protection was obtained in nude mice that received splenocytes at or one and two days before parasite inoculation (present study). This indicates that helper T-cells may play an important part in the resistance of splenic reconstituted nude mice to $P$. berghei.

\section{RESUMO}

Proteção de camundongos atímicos BALB/c (Nu/Nu) contra Plasmodium berghei por 
FERRARONI, J. J.; DOUGLASS, T. G. \& SPEgR, C. A. - Protection of athymic (Nu/Nu) BalB/c mice against Plasmodium berghei by splenocytes from normal $(\mathrm{Nu} /+$ ) BALB/c mice. Rev. Inst. Med. trop. São Paulo 27:303-311, 1985.

\section{esplenócitos oriundos de camundongos normais BALB/c $(\mathrm{Nu} /+)$}

Camundongos atímicos $\mathrm{BALB} / \mathrm{c}(\mathrm{Nu} / \mathrm{Nu})$ sucumbem entre 7-13 dias após a inoculação (DAI) da cepa NK65 de Plasmodium berghei. Todavia, seus singenêicos heterozigotos $(\mathrm{Nu} /+)$ morrem em 7-8 DAI. Camundongos nude $(\mathrm{Nu} / \mathrm{Nu})$ reconstituídos com $2 \times 10^{7}$ esplenócitos de camundongos heterozigotos singenêicos normais não infectados $(\mathrm{Nu} /+) 20$ dias antes da inoculação a (DBI) do parasita, sucumbem 2 dias antes que os animais controles. Camundongos nude reconstituídos 10 ou 2 DBI, vivem 2-4 dias a mais que os animais controles e alguns deles sobrevivem. Esses achados indicam que a cepa NK65 de $P$. ber. ghei induz, no mínimo, dois imunofenômenos dependentes de linfócitos $\mathrm{T}$; um supressivo e outro estimulatório. A reconstituição de camundongos nude com células $T$ de camundongos BALB/c $(\mathrm{Nu} /+)$ parece reduzir ou "By" pass" a atividade supressora das células $T, 0$ qual leva à formação de uma resposta imune protetora por alguns dos camundongos nude.

\section{REFERENCES}

1. BAZAR-MALIK, G. - Increased resistance to malaria after Mycobacterium tuberculosis infection. Indian J. Med. Res. 61: 1014-1024, 1973.

2. BERGHE, V. D. - 4th International Cong. Malaria and Tropical Medicine (1948). In R. Killick-Kendrick and W. Peters (eđs), Rodent Malaria, London, Academic Press, 1978.

3. BROWN, I. N. - Immunological aspects of malaria infection. Advan. Immunol. 11: 267-349, 1970.

4. CAULEY, L. K. \& MURPHX, J. W. - Response of congenitally athymic (nude) and phenotypically normal mice to Cryptococeus neoformans infection. Infect. Immun. 23: 644-651, 1979.

5. CHEERS, C. \& WALLER, R. - Activated macrophages in congenitally athymic "nude" mice and in lenthally irradiated mice. J. Immunol. I15: 844-847, 1975.

6. ClaAK, I. A.; ALLISON, A. C. \& COX, F. E. G. Protection of mice against Babesia and Plasmodium with BCG. Nature (London) 259: 309-311, 1976.

7. CLARK, I. A.; COX, F. E. G. \& ALLISON, A. C. Protection of mice against Babesia spp and Plasmo. dium spp with killed Corynebacterium parvum. Parasitology 74: 9-18, 1977.

8. ELING, W. - Fading of malaria immunity in mice. Z, tropenmed. Parasitol. 29: 77-84, 1978.
9. EMMERLING, P.; FINGER, H. \& BOCKEMUHL, J. - Listeria monocytogenes infection in nude mice. Infect. Immun. 12: 437-439, 1975.

10. FAUVE, R. M. \& HEVIN, B. - Resistance paradoxale des sours thymoprives a l'infection pas Listeria monocytogenes et Salmonella typhimurium et action immunostimulante d'un bacterien phospholipidique (EBP). C. R. Acad. Sci. 279: 1603-1605, 1974.

11. FERRARONI, J. J. \& SPEER, C. A. - Fansidar prophylaxis, therapy and immune responses in rodent malaria (Plasmodium berghei). J. Parasitol. 68: 609-615, 1981.

12. FERRARONI, J. J. \& SPEER, C. A. - Adotive transfer of resistance to Plasmodium berghei with spleen cells and serum from Fansidar-cured mice. Infect. Immun. 36: 1109-1114, 1981.

13. GREENBERG, J. \& KENDRICK, L. P. - Some characteristics of Plasmodium berghei passed within inbred strains of mice. J. Parasitol, 43: 420-427, 1967.

14. HAAIJMAN, J. J.; TEUNISSEN, J. S.; OUDENAREN; A. V.; MINK, J. G. \& BENNER, R. - Kinetics of recovery of serum $\mathrm{Ig}$ levels and of cytoplasmic $\mathrm{Ig}$ positive cells in various lymphoid organs of nude mice after thymus transplantation. Immunology 41: 279-2\%7, 1980 .

15. JAHIEL, R. I.; VILCEK, J.; NUSSENZWEIG, R. S. \&. VANDERBERG, J. - Interferon inducers protect mice against Plasmodium berghei malaria. Seience 161: 802-804, 1968.

16. JAHIEL, R. I.; NUSSENZWEIG, R. S.; VILCET, J. \& VANDERBERG, J. -- Protective effect of interferon inducers of Plasmodium berghei malaria. Am. J. Trop. Med. Hyg. 18: 823-835, 1969.

17. JAHIEL, R. I.; NUSSENZWEIG, R. S.; VILCET, J. \& VANIDERBERG, J. - Anti-malariai effect of interferon inducers at different stages of development of Plasmodium berghei in the mouse. Nature (Londion) 220: 710 $711,1968$.

18. KILLICK-KENDRICK, R. - Parasitic Protozoa of the blood of rodents: A revision of Plasmodium berghei. Parasitology 66: 225-237, 1974.

19. LAIR, S. V. \& LOZZIO, B. B. - Thymocyte reconstitution of athymic and athymic-asplenic mice: Graft rejection and antibody synthesis. Exp. Cell Biol. 48; $439-444,1980$.

20. METCALF, E.; SCHRATER, A. F. \& KLINMAN, N. R - Murine models of tolerance induction in developing and mature B cells. Immunol, Rev. 43: 143-183, 1979.

21. MONGENSEN, S. C. \& ANDERSEN, H. K. - Role of activated macrophages in resistance of congenitally athymic nude mice to hepatitis induced by herpes simplex virus type 2. Infect. Immun. 19: 792-798, 1978.

22. MURPHY, J. R. - Host defenses in murine malaria: Nonspecific resistance of Plasmodium berghei genera. 
FRRRARONI, J. J.; DOUGLASS, T. G. \& SPEER, C. A. - Protection of athymic (Nu/Nu) BALB/c mice against Plasmodium berghei by splenocytes from normal ( $\mathrm{Nu} /+$ ) BALB/c mice. Rev. Inst. Med. trop. São Paulo 2\%:303-311, 1985.

ted in response to Mycobacterium bovis infection or Corynebacterium parvum stimxulation. Infect. Immun. 33: 199-211, 1981.

23. NICKOL, A. D. \& BONVENTRE, P. F. - Anomalous high native resistance of athymic mice to bacterial pathogens. Infect. Immun. 18: 636-645, 1977.

24. NUSSENZWEIG, R. S. - Increased nonspecific resistance to malaria produced by administration of killed Corynebacterium parvum. Exp. Parasitol. 21: 224-231, 1967.

25. NUSSENZWEIG, R. S.; VANDERBERG, J. \& MOST, F. - Protective immunity produced by the injection of X-irradiated sporozoites of Plasmodium berghei. IV. Dose response, especific and humoral immunity. Milit. Med. 134: 1176-1182, 1969.

26. PRAKASHI, S. - Studies on Plasmodium berghei Vincise and Lips, 1948. XXVIY. Duration of patent primary parasitemia necessary for the development of measurable acquired immunity, if any, in the albino mice. Indian J. Malario1. 14: 165-170, 1960.

27. REID, V. E. \& FRIEDKIN, M. - Plasmodium berghei: Folic acid levels in mouse erythrocytes. Exp. Parasitol. 33: 424-428, 1973 .

28. ROGER, T. J.; BALISH, E. \& MANNING, D. D. The role of cell mediated immunity in resistance to experimental candidiasis. J. Reticuloendothel. Soc. 20: $291-298,1976$.

29. SCHRADER, J. W. - The role of $T$ cells in IgG production: Thymus-dependent antigens induce $B$ cell memory in the absence of $\mathrm{T}$ cells. J. Immunol. 114: $1665-1669,1975$.

30. SHULTZ, W. W. ; HUANG, K. Y. \& GORDON, F. B. - Role of interferon in experimental mouse malaria. Nature (London) 220: 709-710, 1968.

31. SMRKOVSKI, L. L. \& STRICKLAND, G. T. - Rodent malaria: BCG-induced protection and immunosuppres. sion. J. Immunol. 121: 1257-1261, 1978.
32. SOUZA, M. de \& PRITCHARD, H. - The cellular basis of immunological recovery in nude mice after thymus grafting. Immunology 26: 769-776, 1974.

33. TANABE, K.; WAKI, S.; TAKADA, S. \& SUZUKI, M - Plasmodium berghei: Suppressed response of antibody-forming cells in the infected mice, Exp. Pararasitol. 43: 143-152, 1977 .

34. TAVERNE, J.; DOCKRELL, H. M. \& PLAYYFAIR, J. H. - Endotoxin-induced serum factor kills malarial parasites in vitro. Infect. Immun. 33: 83-89, 1981.

35. TOBIE, J. E.; WOLF, S. M. \& JEFEERY, G. M. Immune response of man to inoculation with Plasmo. dium cynomolgi and challenge with Plasmodium vivax. Lancet 2: $300 \cdot 303,1966$.

36. TUBBS, H. - Endotoxin in human and murine malaria. Trans. Roy. Soc. Trop. Med. Hyg. "74: 121-123, 1980.

37. WAKI, S. - Protective immunity of Plasmodium herghei in mice induced by repeated infection and chemotherapy. Japan. J. Parasitol. 6: 441-446, 1976.

38. WAKI, S. \& SUZUKI, M. - A study of malaria im. munobiology using nude mice. In Proceedings of the 2nd International Worishop on nude mice. University Tokyo Press, p. 37. Stuttgart, Gustav Fisher Verlag, 1977.

39. WAKI, S, \& SUZUKI, M. - T-independent antibody production in nude mice immunized with a rodent malaria parasite (Plasmodium berghei). In $N, D$. Reed (ed.). Proceedings of the 3rd Internation Workshop on nude mice. New York, Gustav Fisher, 1981.

40. WARD, J. M.; COLLINS, M. J. \& PARKER, J. C. Natural occurring hepatitis virus infection in the nude mouse. Lab. Anim. Sci. 27: 372-376, 1977.

41. WEINTRAUBE, M. - Interferon in malaria. Ann. Int. Med, 37: 1045, 1970.

Recebiđo para publicação em 16/11/1983. 